\title{
How Big is The Role of Micro Small Enterprises(MSEs) and Medium-Large Enterprises (MLEs) in Overcoming Community Income Gaps in Aceh Province ?: Data Analysis of 2016 Economic Census
}

\author{
Ishak Hasan', Azwar ${ }^{2}$, M. Shabri Abd. Majid ${ }^{2}$ \\ Lecturer in Teuku Umar University and Syiah Kuala University, Aceh ${ }^{1}$ \\ Head Section of Cross-Sectoral Statistical Analysis Statistic Center of Aceh Province ${ }^{2}$ \\ Lecturer in Economic and Business Faculty of Syiah Kuala University, Aceh ${ }^{2}$
}

\{ishakhasan20@yahoo.com\}

\begin{abstract}
This study aims to analyze the role of Micro Small Enterprises (MSEs) and Medium-Large Enterprises (MLEs) in addressing income inequality in all districts/cities in Aceh Province and also analyze the most dominant variables that reduce the community income gap. This study uses 2016 Economic Census of BPS province of Aceh for 23 districts/cities and Gini Ratio for community income gap variables. The results showed that the number of MSEs units, the average MSEsworkers, the total wages received by the SMEs workers, the SMEs wage average, and the district/city economic growth in 2016 had a significant effect on the income inequality in the districts/cities of Aceh Province. While the number of MSEs workers, the number of MLEs units, the number of MLEs workers, the average of MLEs workers, the total wages of MLEs workers, and the average wage of MLEsworkers have not significantly influence to the community income gap. The only factor that has a significant influence in reducing the gap in community income is the total remuneration (wages) received by MSEs workers. The recommendation that can be given to be implemented immediately for the Aceh government is to strengthen MSEs, including cooperatives as the drivers of the Aceh's economic which can absorb more labor and compensation or wages received by workers also increases. Furthermore, the Government of Aceh, in this case, the Provincial Manpower Office and the Office that manages labors all districts/cities must monitor the application of the Provincial Minimum Wage (PMW) for MSEs which have been under-emphasized for various reasons and consider.
\end{abstract}

Keywords: Micro Small Enterprises, Medium Large Enterprises, Gini Ratio

\section{Introduction}

Aceh's economy is currently influenced by the activities of Micro Small Enterprises (MSEs) and Medium-Large Enterprises (MLEs). Both of these business scales are able to absorb more than one million labors in the agricultural category, even though the agricultural sector still plays an important role. Data based on the 2016 Economic Census makes the initial step to measure the strength of Aceh's economy outside the agricultural sector.

The results of the 2016 Economic Census (EC) recorded that the number of Micro Small Enterprises (MSEs) and Medium-Large Enterprises (MLEs) in Aceh Province is 432,819 business units. This figure has increased by 17.54 percent when compared with the results of the 2006 EC which amounted to 368,244 business units. North Aceh District has 48,023 units in 2006 and 50,392 units in 2016.

Micro Small Enterprises (MSEs) in Aceh are currently dominating the economic activities with a proportion of 98.74 percent. While MLEs only reached 1.26 percent (5.5 thousand units) which was concentrated only in Banda Aceh City, Lhokseumawe City, Aceh Besar Regency, Bireuen Regency, and North Aceh Regency (52.75 percent). The contribution of MSEs and MLEs activities is a fundamental strength for the Acehnese economy. According to the Central Bank of Indonesia publications in May 2018, MSEs and MLEs in Aceh are one of the largest coffee production in Indonesia. Both Robusta and Arabica coffee [1].

Strengthening Aceh's economy is inseparable from the improved social conditions of the community and various economic activities that show rapid development. The construction sector, education services, and financial activities in 2016 became a barometer of the sustainability of Aceh's economic growth. The achievement of economic growth based on this sector is very high and always above Aceh's economic growth recorded at 4.31 percent (non-oil and gas) in 2016. This shows an encouraging achievement to sustain Aceh's economic growth on an ongoing basis (BPS Provinsi Aceh, 2017).

In contrast to the growth rate, in terms of quantity, the most widely run business fields are wholesale and retail trade, repair and maintenance of cars and motorbikes (category $\mathrm{G}$ ) reaching 44.82 percent. While the manufacturing 
industry (category C), and the provision of accommodation and food supply (category I) are the second and third largest economic activities each 20.16 percent and 15.59 percent respectively.

Business with category $\mathrm{G}$ (wholesale and retail trade, repair and maintenance of cars, and motorbikes), categories $\mathrm{P}$ (Education), C (processing industry), and category I (providing accommodation and providing food and beverage) absorb more than three-quarters of the workforce non-agricultural employment in the Province of Aceh (76.10 percent). While other business categories have contributed below seven percent each (BPS Provinsi Aceh, 2017).

Although the average units number of MSEs and MLEs businesses in each district and city in Aceh Province has increased, there are four regencies that have experienced a decline in the units number of businesses, including Southeast Aceh District, down 7.47 percent, Pidie 8.45 percent, Nagan Raya 10, 37 percent and Aceh Jaya amounted to 16.62 percent. The comparison of the units number of businesses in 2006 and 2016 can be seen in Figure 1 below

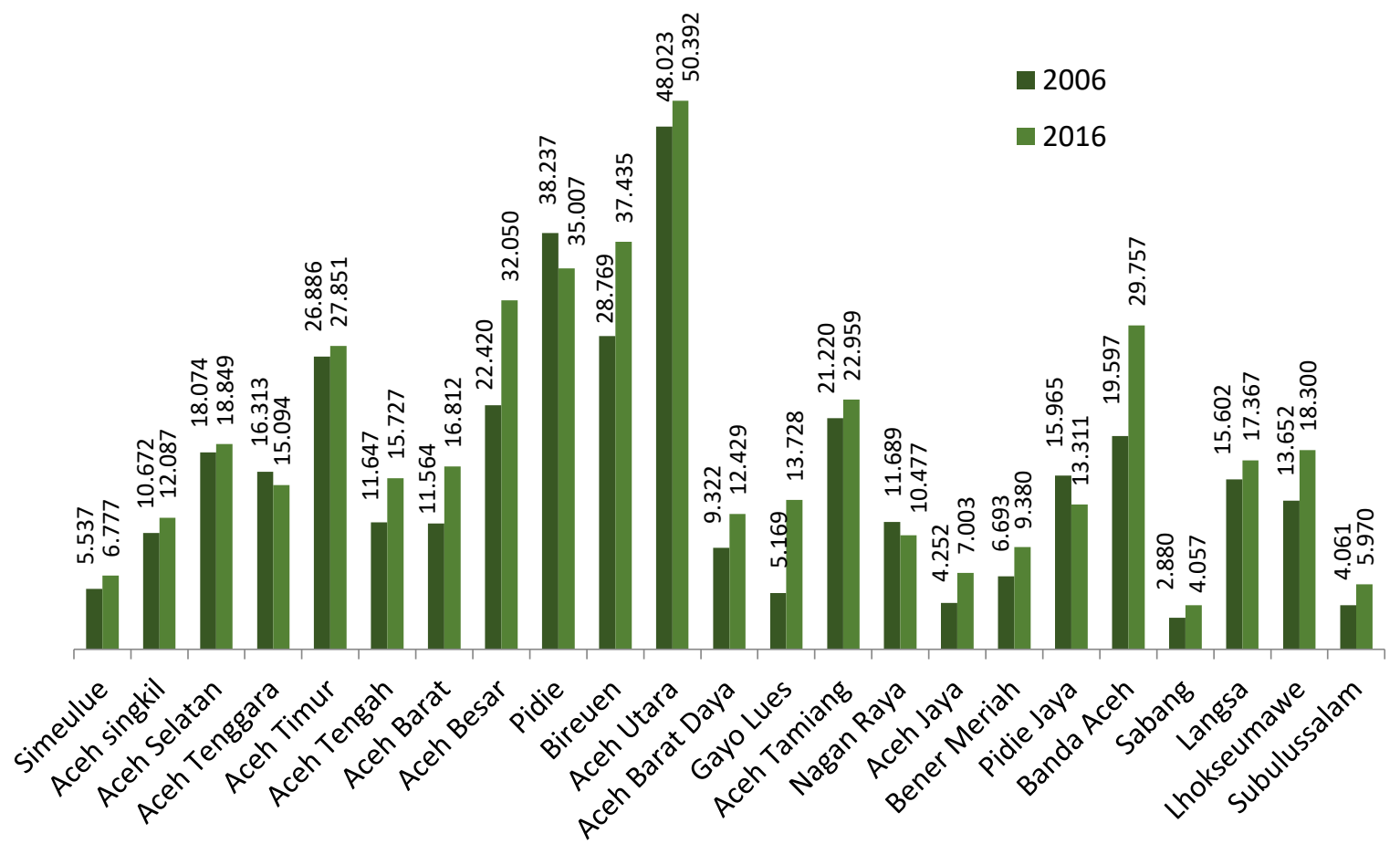

Figure 1. Comparison of the number of MSEs and MLEs in Aceh province Source : BPS ( http://se2016.bps.go.id/)

Basically, the trend of MSEs and MLEsunits in each region will probably increase from year to year. This is in line with the GRDP target of each region every year which tends to increase. Decreasing the number of MSEs and MLEs in an area can reduce the regional income itself. The number of business units/companies can also be a barometer of the successful of the government in building the economic infrastructure of a region.

The facts show that the MSEs and MLEs are believed to be able to overcome the income gap in the community, of course, it affects the economy in every district and city of Aceh Province. Based on the above conditions, this research aims to:

1. Analyzing MSEs and MLEs components (number of business units, number of workers, average workers, total wages, and average wages) play a role in overcoming the income gap in Aceh Province

2. Explain the MSEs and MLEsvariables that are dominant in reducing the community income gap in Aceh Province. 


\section{Literature Study}

There are many concepts and definitions that explain businesses and companies and the factors that influence them. This study refers to the concept described by Law No. 20 of 2008 [3] concerning micro, small and medium enterprises as follows:

1. Micro Enterprises are productive businesses owned by individuals and/or individual business entities, having a net worth of at most 50 million rupiahs, not including land and buildings and having annual sales of at most 300 million rupiahs.

2. Small Enterprises is a stand-alone productive economic business carried out by an individual or business entity that is not a subsidiary or not a branch of a company that is owned, controlled or becomes a direct or indirect part of a medium or large business. Having a net worth of more than 50 millionrupiahs up to a maximum of 500 million rupiahs, not including land and buildings or having annual sales of more than 300 million rupiahs up to a maximum of 2.5 billion rupiahs.

3. Medium Enterprises is a stand-alone productive economic business carried out by an individual or business entity that is not a subsidiary or branch of a company that is owned, controlled or directly or indirectly part of a small business or large business with a net wealth or annual sales revenue. Having a net worth of more than 500 million rupiahs up to a maximum of 10 billion rupiahs, not including land and buildings or having an annual sales of more than 2.5 billion rupiahs up to a maximum of 50 billion rupiahs.

Likewise, studies on MSEs and MLEs in relation to economic activities have been widely carried out by experts. J.A Schumpeter'stheory emphasizes the importance of entrepreneurs role in creating economic growth. In his theory, entrepreneurs are groups that will continue to make renewal or innovation in economic activities. According to Schumpeter, the higher the level of economic progress, the more limited is to carry out innovations, economic growth becomes slower which will eventually reach "stationary state" [4]. Furthermore, Harrod-Domar's growth theory states that if you want to grow, the economy must save and invest a certain proportion of the total output. The more savings and then invested, the faster the economy will grow [5].

In general, Community empowerment policy can be divided into three groups. First, a policy that does not directly lead to targets but provides a basis for achieving an atmosphere that supports community socio-economic activities. Second, policies that directly lead to increased target economic activities. Third, specific policies that reach the poor through special efforts, in the form of policies that directly lead to the improvement of the target group's economics group, the goal of the development is to pay attention to the process of equity or the distribution of added value formed in economic activities in a region. The distribution process needs to be observed considering that the failure of this process will have an impact on social turmoil because this inequality will be responded to by the lower class. To see the inequality of population income, one indicator that is often used is the Gini coefficient [6].

Fred \& Dominick [7] revealed that the study of income distribution is a topic that has been neglected in economics studies. Likewise [8] states that economic growth has consequences on high inequality because it provides obstacles to mobility between regions. This is in line with Kuznets [9] which states that in the early stages of economic growth, income distribution tends to deteriorate, but in later stages, income distribution will improve. This observation is then identified as the Kuznets curve "inverted U" due to longitudinal changes in income distribution [10].

Many studies have covered a lot about Micro, Small and Medium Enterprises (MSMEs) or Small and Medium Enterprises (SMEs) as the subject of research. There is also a link between the number of MSMEs or MSME growth in economic growth in their respective regions. The study conducted by Supriyanto [11] revealed that poverty alleviation by developing MSMEs has good potential. It turns out that the MSME sector has a large contribution to employment, which absorbs more than 99.45 percent of the workforce and contributes to GDP of around 30 percent. Efforts to promote and develop the MSME sector that absorbs more workers can improve the welfare of the workers involved in it, thereby reducing unemployment and poverty.

According to Sudiyarti \& Irwansyah [12] the growing number of Micro, Small and Medium Enterprises (MSMEs) in Sumbawa regency, West Nusa Tenggara Province, is increasingly influencing the regional economic growth so that in the long run MSMEs can spur increased economic growth in the area.

Reswary [13] examines the "analysis of the factors influencing the unit number of industries in Surabaya" using the variables of labor, foreign exchange rates, investment, and inflation. The results of the research show that labor has a significant effect on the unit number of industries in Surabaya. While partially foreign exchange rates, investment, inflation, and industry have no influence or insignificance on the unit number of industries in Surabaya.

Tambunan [14] presents the results of research that MSEs have an important role as one of the ways to reduce poverty in regions (provinces), but their roles vary by the province which is determined by differences in access to MSEs to important inputs, such as education, technical assistance, raw materials, and capital. Likewise, Abduh [15] analyzed the determinants of the growth of micro, small and medium enterprises in Indonesia. The result shows that 
per capita income and government spending have a positive and significant impact on the growth of MSMEs in Indonesia.

In addition, Bustam [16] mentions that the number of Micro, Small and Medium Enterprises (MSMEs), GDP of Micro, Small and Medium Enterprises (MSMEs) and investments simultaneously affect employment. Variations in factors that affect labor absorption are explained by the variable number MSME units, MSME GDP and investment which together affect 99.7 percent while the remaining 0.3 percent is explained by other variables outside of research.

Hapsari, Hakim, \& Soeaidy [17] in his research explained that SMEs play an important role in the regional economy, especially in creating employment opportunities. This is based on the fact that on the one hand if the number of unemployed increases following the number of population growth each year, it must be balanced with the creation of new jobs support, like MSEs. The type of MSEs which is relatively labor intensive makes it possible to assist the absorption of unabsorbed labor. From supporting natural potential, Batu city has criteria for the growth of the MSEs business climate.

Furthermore, the number of companies/businesses from various business sectors can influence other variables, such as employment, GRDP, etc. Various studies conducted by several researchers explained the link between the number of businesses/companies from various sectors to the variables they influence. According to [18] there is an influence of industrial sector growth on employment in Sidoarjo regency in 2009-2015. The results of this study indicate that the growth of the industrial sector has a significant effect on employment (positive sign). That is, when the growth of the industrial sector increases, employment also can be increased

Contrary to Herawati and Yoyok which revealed that industrialization activities also had an inverse relationship to the employment in Blitar Regency, Mahendra [19] examined the relationship between the number of industries and the absorption of labor having a negative relationship. The more the increase in the number of industries, the less labor absorbed, on the contrary, the less increase in the number of industries, the more labor is absorbed. This is also evidenced by the regression results that the influence of the number of industries on labor absorption in the wood lathe industry is not elastic. With the decline in the number of industries means that there is an additional employment opportunity so that there will be an increasing demand for new labor.

Inequality is a broader concept of poverty because it is defined based on the entire population, not only on the part of the population that is below a certain poverty line. Most measures of inequality do not depend on distribution averages, measures of inequality are often calculated for distributions other than expenditure, e.g income, land, assets, tax payments, and other basic variables [20].

Other studies related to income inequality are relatively large. Abdulah [21] conducted research on the factors that influence income inequality in Central Java. The results show that there are only two significant variables that cause inequality, namely the economic output share received by employers and wages. While the other two are insignificant namely urbanization and dependency ratio.

While Ramakrishnan \& Cerisola [22] studied regional economic disparities in Australia. The results show that increases in real wages, productivity, and increases in state subsidy spending can reduce the unemployment rate so that it can slowly reduce economic disparities between regions in Australia.

Furthermore, Meliciani [23] examines income disparities between regions of the European Union which produce two main conclusions. First, the gap in the EU region has declined since the last 1990s. Second, the gap can decrease if using labor productivity variables rather than per capita income.

Likewise, Azwar, Hamzah, Masbar, \& Syahnur [24] conducted an analysis of the economic growth gap between regions in the province of Aceh using panel data 2000-2010. The results showed that the only significant variable that could reduce the gap was the Human Development Index. While the cumulative effect of the region (cumulative causation effect) and per capita GRDP significantly but positively.

This research is explanatory which aims to explain the relationship between variables, is assumed to have a linear causality relationship that is a relationship (causation) involving 2 types of variables, namely independent variables that affect the dependent variable.

Based on the objectives of the research submitted and literature studies that have been presented and related research results, this research has the following theoretical framework: 


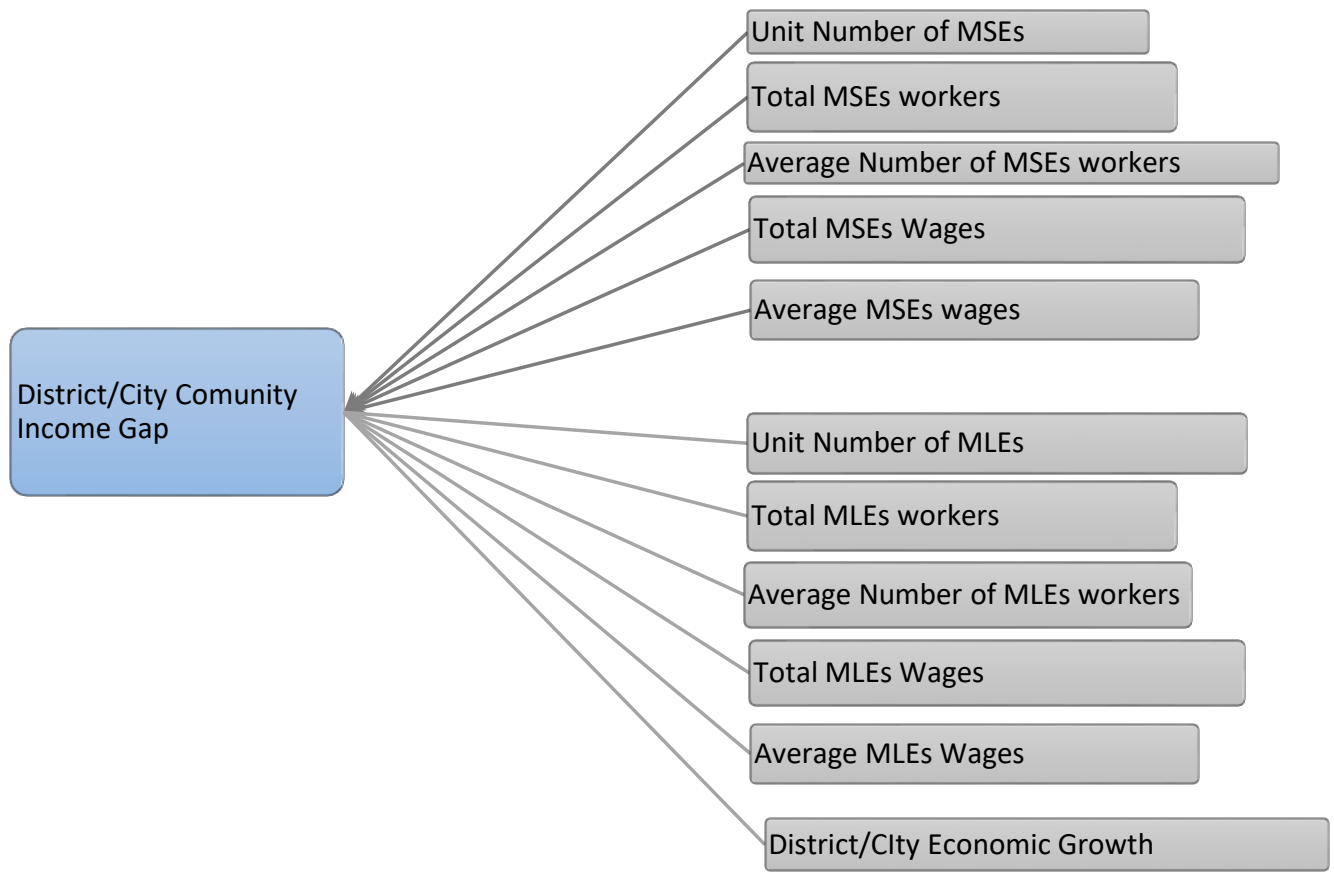

Figure 2. Theoretical Framework

\section{Analysis Model}

This study covers 23 regencies and cities in the province of Aceh. In addition, this study is limited by the number of variables studied, chosen based on studies/literature studies conducted on the basis of limitations and availability of data. Other studies will make it possible to get different results if you use different variables.

The data presented are a cross section, sourced from BPS data from the 2016 Economic Census activities and several other BPS data. This study uses 12 (twelve) variables, among others; community income gap (Y), number of MSEs units $\left(\mathrm{X}_{1}\right)$, number of SMEs workers $\left(\mathrm{X}_{2}\right)$, average MSEs workers $\left(\mathrm{X}_{3}\right)$, total MSEs workers wages $\left(\mathrm{X}_{4}\right)$, average MSEs wages $\left(X_{5}\right)$, the number of MLEsunits $\left(X_{6}\right)$, the number of MLEsworkers $\left(X_{7}\right)$, the average MLEsworkers $\left(\mathrm{X}_{8}\right)$, the total MLEsworkers wage $\left(\mathrm{X}_{9}\right)$, the

MLEs average wage $\left(\mathrm{X}_{10}\right)$, and the district/city economic growth $\left(\mathrm{X}_{11}\right)$

The next stage is to analyze the relationships between variables as well as to examine the MSEs and MLEs independent variables that predominantly affect the income gap of the community as the dependent variable. This study uses a multiple regression model, to analyze the influence of MSEs and MLEs variables on the income gap of district/city communities in Aceh province. Furthermore, it also examines the variables that can reduce the income gap.

Furthermore, the pattern of relationships that occur is assumed to follow a straight line pattern with one dependent variable and several independent variables. The relationship between variables in multiple linear regression models is formulated into the equation as follows:

$$
\begin{aligned}
& \boldsymbol{Y}=\alpha+\sum_{i=1}^{N}\left(\beta_{i} \boldsymbol{X}_{i}+\varepsilon_{i}\right) \ldots \ldots \ldots \ldots \ldots \ldots \ldots \ldots \ldots \ldots \\
& \boldsymbol{Y}=\alpha+\beta_{1} \boldsymbol{X}_{1}+\beta_{2} \boldsymbol{X}_{2}+\ldots+\beta_{N} \boldsymbol{X}_{N}+\varepsilon_{1}+\varepsilon_{2}+\cdots+\varepsilon_{N}
\end{aligned}
$$

Note :

Y : Dependent variable/response variable

$\alpha \quad$ : Intercept (constant values obtained when all regression coefficients are "zero")

$\beta_{i} \quad$ : The regression coefficient on the variable to i /slope

$\boldsymbol{X}_{i} \quad$ : Independent variable/predictor i

$\varepsilon_{i} \quad$ : Residual (the amount of value obtained outside of the independent variables studied)

The model is a model for parameters, so it is necessary to observe the value of the entire population in order to get the value. There are limitations in taking the population observation value and the difficulty of calculating the value of each residual and coefficient. It is necessary to estimate the magnitude of each coefficient. 
There are several methods to estimate the regression coefficients of the model, the simplest is to use the Ordinary Least Squares method (least squares equation). This method is used because it meets the requirements in estimating a model and is also a "BLUE" or Best Linear Unbiased Estimator. That is mean, the OLS method is the best estimation method for estimating linear models and this method is also unbiased.

Based on the models formulated in equations (1) and (2), the following models are produced:

$$
\begin{gathered}
\widehat{\boldsymbol{Y}}=\hat{\alpha}+\sum_{i=1}^{N} \hat{\beta}_{i} \boldsymbol{X}_{i} \ldots \ldots \ldots \ldots \ldots \ldots \\
\widehat{\boldsymbol{Y}}=\hat{\alpha}+\hat{\beta}_{1} \boldsymbol{X}_{1}+\hat{\beta}_{2} \boldsymbol{X}_{2}+\cdots+\hat{\beta}_{n} \boldsymbol{X}_{n}
\end{gathered}
$$

Note :

$\widehat{\boldsymbol{Y}} \quad$ : The estimated value of the dependent variable / response variable

$\hat{\alpha} \quad:$ Intersep estimation value

$\hat{\beta}_{i} \quad$ : The estimated value of the regression coefficient on the variable $\mathrm{i}$

$\boldsymbol{X}_{i} \quad$ : Independent variables / predictors to i

If equation (4) we substitute into the variables to be studied, produce the following models:

$\widehat{\boldsymbol{Y}}=\hat{\alpha}+\hat{\beta}_{1} \boldsymbol{X}_{1}+\hat{\beta}_{2} \boldsymbol{X}_{2}+\hat{\beta}_{3} \boldsymbol{X}_{3}+\hat{\beta}_{4} \boldsymbol{X}_{4}+\hat{\beta}_{5} \boldsymbol{X}_{5}+\hat{\beta}_{6} \boldsymbol{X}_{6}+\hat{\beta}_{7} \boldsymbol{X}_{7+}+\hat{\beta}_{8} \boldsymbol{X}_{8}+\hat{\beta}_{9} \boldsymbol{X}_{9}++\hat{\beta}_{10} \boldsymbol{X}_{10}+\hat{\beta}_{11} \boldsymbol{X}_{11}$

Note :

$\widehat{\boldsymbol{Y}} \quad$ : District / city community income gap 2016

$\hat{\alpha} \quad:$ Intersep estimation value

$\hat{\beta}_{i} \quad:$ The estimated value of the regression coefficient on the variable $\mathrm{i}$

$\boldsymbol{X}_{1} \quad$ : Number of MSEs units in 2016

$\boldsymbol{X}_{2} \quad$ : Number of MSEs workers in 2016

$\boldsymbol{X}_{3} \quad$ : The average of MSEs workers in 2016

$\boldsymbol{X}_{4} \quad$ : Total labor wages of MSEsin 2016

$\boldsymbol{X}_{5} \quad$ : Wages Average of MSEs in 2016

$\boldsymbol{X}_{6} \quad$ : Number of MLEs units in 2016

$\boldsymbol{X}_{7} \quad$ : Number of MLEsworkers in 2016

$\boldsymbol{X}_{8} \quad$ : The average of MLEsworker in 2016

$\boldsymbol{X}_{9} \quad$ : Totalworkers wages of MLEsin 2016

$\boldsymbol{X}_{10}$ : Wages Average of MLEs in 2016

$\boldsymbol{X}_{11} \quad$ : Regency / city economic growth in 2016

\section{Result and Discussion}

To analyze the influence of MSEs and MLEs variables (the number of MSEs units, the number of MSEs workers, the average MSEs workers, the total wages of MSEs workers, the average wages of MSEs, the number of MLEs units, the number of MLEs workers, the average workers of MLEs, the total wage of MLEs workers, the average wages of MLEs), and the economic growth of the regency and city against the income gap of the regencies and cities in Aceh Province, as previously described using the analysis model as follows:

$\widehat{\boldsymbol{Y}}=\hat{\alpha}+\hat{\beta}_{1} \boldsymbol{X}_{1}+\hat{\beta}_{2} \boldsymbol{X}_{2}+\hat{\beta}_{3} \boldsymbol{X}_{3}+\hat{\beta}_{4} \boldsymbol{X}_{4}+\hat{\beta}_{5} \boldsymbol{X}_{5}+\hat{\beta}_{6} \boldsymbol{X}_{6}+\hat{\beta}_{7} \boldsymbol{X}_{7+}+\hat{\beta}_{8} \boldsymbol{X}_{8}+\hat{\beta}_{9} \boldsymbol{X}_{9}++\hat{\beta}_{10} \boldsymbol{X}_{10}+\hat{\beta}_{11} \boldsymbol{X}_{11}$

…..........(5)

Note :

$\widehat{\boldsymbol{Y}} \quad$ : District/city community income gap 2016

$\hat{\alpha} \quad:$ Intersep estimation value

$\hat{\beta}_{i} \quad:$ The estimated value of the regression coefficient on the variable $\mathrm{i}$

$\boldsymbol{X}_{1} \quad$ : Number of MSEs units in 2016

$\boldsymbol{X}_{2}$ : Number of MSEs workers in 2016

$\boldsymbol{X}_{3} \quad$ : The average of MSEs workers in 2016

$\boldsymbol{X}_{4} \quad$ : Total labor wages of MSEsin 2016

$\boldsymbol{X}_{5} \quad$ : Wages Average of MSEs in 2016

$\boldsymbol{X}_{6} \quad$ : Number of MLEs units in 2016

$\boldsymbol{X}_{7} \quad$ : Number of MLEsworkers in 2016

$\boldsymbol{X}_{8} \quad$ : The average of MLEsworker in 2016 


\begin{abstract}
$\boldsymbol{X}_{9} \quad$ : Totalworkers wages of MLEsin 2016
$\boldsymbol{X}_{10}$ : Wages Average of MLEs in 2016

$\boldsymbol{X}_{11} \quad$ : Regency / city economic growth in 2016

Based on the data processing that has been carried out, the results obtained are as shown in Tables 1, 2 and 3 below.
\end{abstract}

Table 1. Model Summary ${ }^{\mathrm{a}}$

\begin{tabular}{ccccc} 
Model & $\mathrm{R}$ & $\mathrm{R}$ Square & $\begin{array}{c}\text { Std. The error of the } \\
\text { Estimate }\end{array}$ & Durbin-Watson \\
\hline 1 & $.888^{\mathrm{a}}$ & .789 & .01825 & 1.936
\end{tabular}

a. Predictors: (Constant), the number of MSEs units, the number of MSEs workers, the average MSEs workers, the total wages of MSEs workers, the average wages of MSEs, the number of MLEs units, the number of MLEs workers, the average workers of MLEs, the total wage of MLEs workers, the average wages of MLEs

b. Dependent Variable: Income gap

The test of the coefficient of determination (R Square) is used to measure the goodness of fit of a model, which gives the proportion of total variation in the dependent variable explained by the independent variable (Gujarati, 2004). The amount of R Square ranges from $0 \leq \mathrm{R} 2 \leq 1$, where if $\mathrm{R}$ Square gets closer to one, a model is said to be good because the higher the variation of the dependent variable can be explained by the independent variable.

From Table 1 above shows that the size of R Square is 0.789 or 78.90 percent. This means that the dependent variable (community income gap) can be

explained by variations in the independent variables (number of MSEs units, number of MSEs workers, average MSEs workers, total wages of MSEs workers, average wage of MSEs workers, number of MLEs units, the number of MLEs workers, the average of MLEs workers, the total wages of MLEs workers, the average wage of MLEs workers, and the economic growth of regencies / cities) of 0.789 or78.9 percent. While the remaining 0.212 or 21.1 percent is caused by other variables outside the model (outside of research).

Table 2. Simultaneously Test ${ }^{\mathrm{b}}$ (ANOVA Table)

\begin{tabular}{llccccc}
\hline \multicolumn{1}{c}{ Model } & Sum of Squares & Df & Mean Square & F & Sig. \\
\hline \multirow{3}{*}{1} & Regression & .014 & 11 & .001 & 3.740 & $.019^{\mathrm{b}}$ \\
\cline { 2 - 6 } & Residual & .004 & 11 & .000 & & \\
\cline { 2 - 7 } & Total & .017 & 22 & & & \\
\hline
\end{tabular}

a. Dependent Variable: Income gap

b. Predictors: (Constant), ), the number of MSEs units, the number of MSEs workers, the average MSEs workers, the total wages of MSEs workers, the average wages of MSEs, the number of MLEs units, the number of MLEs workers, the average workers of MLEs, the total wage of MLEs workers, the average wages of MLEs

The $\mathrm{F}$ test is basically used to prove the simultaneous effect of all independent variables of MSEs and MLEs (number of MSEs units, number of MSEs workers, average MSEsworkers, total wages of MSEsworkers, average wage of MSEs workers, number of MLEsunits, number of MLEs workers, the average of MLEsworkers, the total wage of MLEs workers, the average wage of MLEs workers, and the economic growth of regencies / cities) against the variable income gap.

Based on Table 2 above, it can be seen that the $F$ count is 3.740 with a probability of 0.019 . With a probability of 0.019 (less than the degree of error), it means that the MSEs and MLEs variables (number of MSEs units, number of MSEs workers, average MSEsworkers, total wages of MSEsworkers, average wage of MSEs workers, number of MLEs units, number of MLEs workers, the average of MLEs workers, the total wage of MLEs workers, the average wage of MLEs workers, and the economic growth of regencies / cities) simultaneously have a significant effect on the variable income gap. 
Table 3. Partial test (t-test)

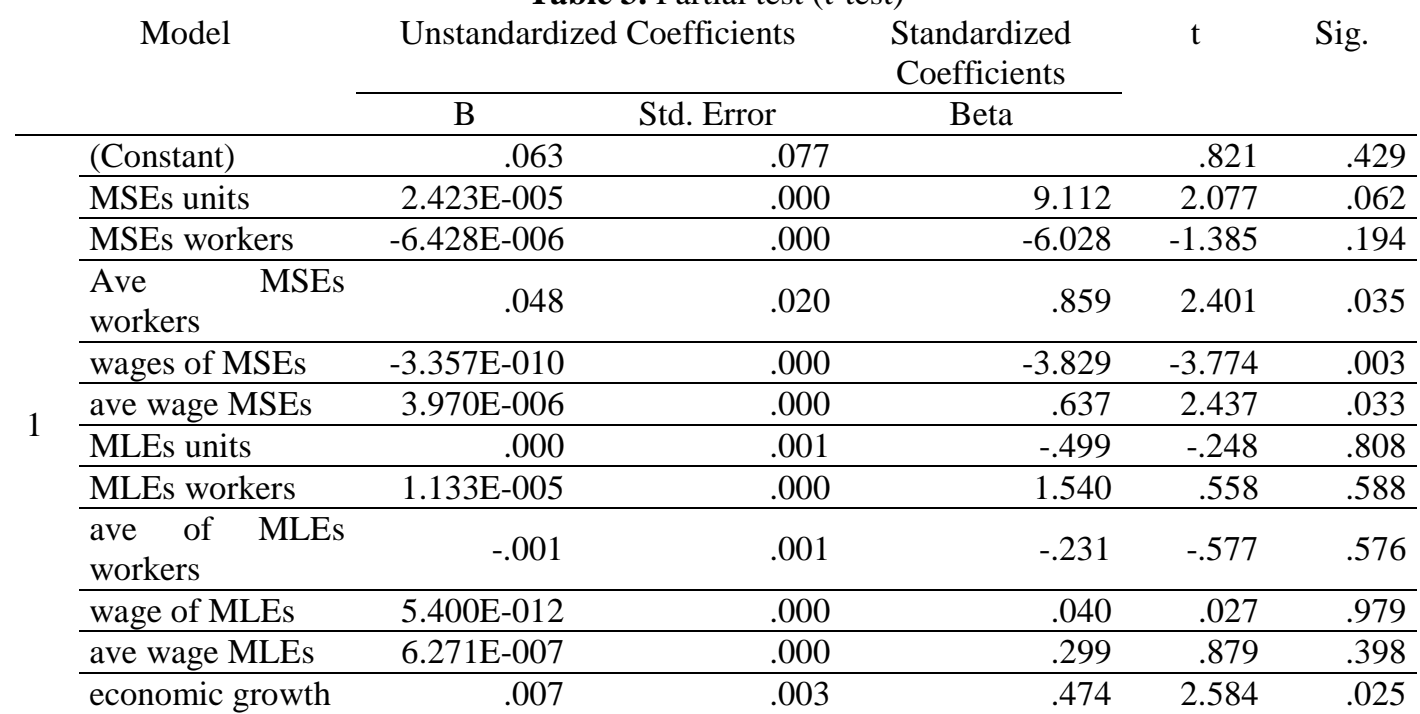

The partial test (t-test) aims to analyze the independent variables have a partial significant effect on the dependent variable. Based on Table 3, it shows that the number of MSEs units, the average MSEs workers, the total remuneration (wages) received by the MSEs workers, the average wage of MSEs workers, and the economic growth of regencies/cities in 2016 significantly affected the income gap community in the provincial district/city of Aceh. While the number of MSEs workers, the number of MLEs units, the number of MLEs workers, the average of MLEs workers, the total wages of MLEs workers, and the average wage of MLEsworkers did not significantly influence on the community income gap. The only variable that has a significant effect on reducing the income gap in the community is the total remuneration (wages) received by MSEs workers. That is, the greater the total wages received by laborers, the more prosperous workers who receive income, even more equally the distribution of community income, so that the disparity in the income of the people of Aceh province can be suppressed

The number of MSEsworkers does not significantly influence the income gap due to many MSEsworkers not being paid because they employ family members as workers, including business owners who do not count on wages.

The number of MLEs units, the number of MLEsworkers, the average of MLEs workers, the total wages of MLEs workers, and the average wage of MLEsworkers does not significantly influence to the community income gap. This is because the number of MLEs units only has a proportion of 1.26 percent ( 5.5 thousand units) of business when compared to MSEs recorded 98.74 percent of the total 432.8 thousand businesses. Another cause, MLEs is concentrated only in five districts/cities, including the City of Banda Aceh, Kota Lhokseumawe, Kabupaten Aceh Besar, Bireuen District, and North Aceh Regency (52.75 percent). The uneven scale of the MLEs business in the province of Aceh is believed to be a trigger for not being able to overcome the community income gap because it is concentrated in five districts/cities. In addition, because the number of business units is relatively limited, of course, the labor absorbed is also small so that unemployment continues to increase. 


\section{Conclusions And Recommendations}

\subsection{Conclusion}

The number of MSEs units, the average MSEs workers, the total wages of MSEs workers, the average wage of MSEs workers, and the economic growth of regencies/cities in 2016 significantly affected the community income gap in the provincial districts/cities of Aceh. While the number of MSEs workers, the number of MLEs units, the number of MLEs workers, the average of MLEs workers, the total wages of MLEs workers, and the average wage of MLEs workers did not significantly influence the community income gap. The only factor that has a significant influence in reducing the income gap is the total compensation (wages) received by MSEs workers.

\subsection{Recommendation}

Based on the conclusions above which stated that the only variable that significantly affected the community income gap was the total remuneration (wages) received by MSEs workers. Based on these conclusions, this study provides some recommendations to the Aceh government as policy-holder authorities to be implemented immediately. Recommendations that can be given are to strengthen Micro Small Enterprises (MSEs), including cooperatives as a driver of the Aceh economy, increasing the number of MSE units that can absorb labor so that rewards/wages received by workers also increase, automatically reducing community income gaps in all district/city of Aceh province. Furthermore, the Government of Aceh and district/city governments, especially the Manpower Office, encouraged all MSEs to provide wages in accordance with the Aceh UMP (provincial minimum wages ) in 2018 amounting to 2,7 million rupiahs. Because all MLEs variables are not significant in overcoming community income gaps, the Aceh and Regency / CityInvestment Services immediately pushed the number of MLEs to increase its growth and focused more on 18 (eighteen) other regencies/cities. The uneven scale of MLEs business in Aceh province is believed to be a trigger of not being able to overcome the community income gap because it is only concentrated in five district/city.

\section{REFERENCES}

[1] Bank Indonesia, "Kajian ekonomi dan keuangan regional,” 2018.

[2] Badan Pusat Statistik Provinsi Aceh, "Data hasil pendaftaran usaha/perusahaan sensus ekonomi 2016 provinsi aceh," 2017. .

[3] Presiden Republik Indonesia, Undang-Undang Republik Indonesia Nomor 20 Tahun 2008. 2008.

[4] S. Sukirno, Makro ekonomi teori pengantar. Jakarta: PT Raja Grafindo Persada, 2011.

[5] Subandi, Ekonomi pembangunan. Bandung: Alfabeta, 2012.

[6] M. Kuncoro, Perencanaan daerah: Bagaimana membangun ekonomi lokal, kota, dan kawasan? Jakarta: Salemba Empat, 2012.

[7] C. Fred and S. Dominick, Income distribution. London: Oxford University Presss, 2006.

[8] M. Corak, "Income inequality, equality of opportunity, and intergenerational mobility," J. Econ. Perspekt., vol. 27, no. 3, pp. 79-102, 2013.

[9] S. Kuznets, "Economic growth and income inequality," Am. Econ. Rev., vol. 1, no. 45, 1955.

[10] M. P. Todaro and S. C. Smith, Pembangunan ekonomi. Jakarta: Penerbit Erlangga, 2006. 
[11] Supriyanto, "Pemberdayaan usaha mikro, kecil, dan menengah (UMKM) sebagai salah satu upaya penanggulangan kemiskinan,” J. Ekon. Pendidik., vol. 3, no. 1, pp. 1-16, 2006.

[12] N. Sudiyarti and A. Irwansyah, "Pengaruh usaha mikro kecil menengah (UMKM) terhadap pertumbuhan ekonomi daerah kabupaten sumbawa tahun 2011-2015," J. Ekon. dan Bisnis, vol. 14, no. 2, pp. 130-143, 2017.

[13] A. A. Reswary, "Analisis faktor-faktor yang mempengaruhi jumlah industri di Surabaya," Universitas Pembangunan Nasional "Veteran” Surabaya, 2012.

[14] T. T. H. Tambunan, "Peran usaha mikro kecil dalam pengentasan kemiskinan di daerah," Bina Praja J., pp. 73-92, 2012.

[15] T. Abduh, "Determinan pertumbuhan usaha mikro, kecil, dan menengah (UMKM) pada provinsi di indonesia," Universitas“45” Makassar, 2018.

[16] N. H. Bustam, "Pengaruh jumlah unit, pdb dan investasi umkm terhadap penyerapan tenaga kerja di indonesia periode 2009-2013," Kutubkhanah J. Penelit. Sos. keagamaan, vol. 19, no. 2, pp. 250-261, 2016.

[17] P. P. Hapsari, A. Hakim, and S. Soeaidy, "Pengaruh pertumbuhan usaha kecil menengah (UKM) terhadap pertumbuhan ekonomi daerah (studi di pemerintah kota batu)," Wacana, vol. 17, no. 2, pp. 88-96, 2014.

[18] H. Purwasih and Y. Soesatyo, "Pengaruh pertumbuhan sektor industri terhadap penyerapan tenaga kerja kabupaten sidoarjo," J. Pendidik. Ekon., vol. 5, no. 1, pp. 1-6, 2015.

[19] R. Mahendra, "Pengaruh jumlah industri dan kapasitas produksi terhadap penyerapan tenaga di kota blitar (studi pada industri kayu bubut di kelurahan tanggung kota blitar)," Universitas Brawijaya, 2013.

[20] J. Haughton and S. R. Khandker, Pedoman tentang kemiskinan dan ketimpangan: Handbook on poverty and inequality. Jakarta: Selemba Empat, 2012.

[21] R. Abdulah, "Faktor-faktor yang memengaruhi ketimpangan pendapatan di jawa tengah," Jejak, vol. 6, no. 1, pp. 42-53, 2013.

[22] U. Ramakrishnan and M. Cerisola, "Regional economic disparities in Australia.," 2004.

[23] V. Meliciani, "Income and employment disparities across european regions: The role of national and spatial factors," Reg. Stud., vol. 40, no. 1, pp. 75-91, 2006.

[24] Azwar, A. Hamzah, R. Masbar, and S. Syahnur, "Economic growth disparity among the regions in Aceh, Indonesia,” Aceh Int. J. Soc. Sci., vol. 2, no. 1, pp. 21-31, 2013. 